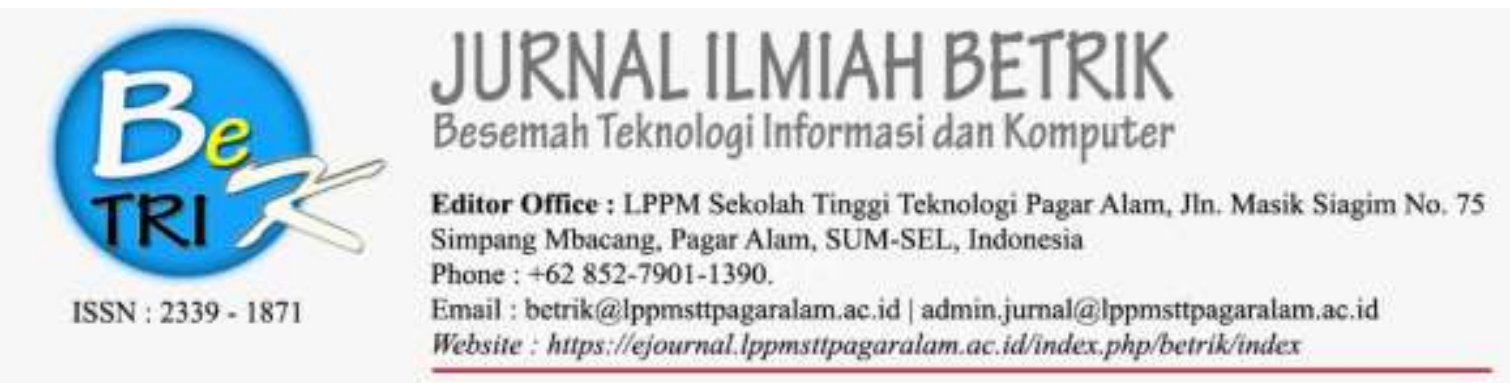

\title{
RANCANG BANGUN WEBSITE DINAS PENGENDALIAN PENDUDUK KELUARGA BERENCANA PEMBERDAYAAN PEREMPUAN DAN PERLINDUNGAN ANAK KOTA PAGAR ALAM
}

\author{
Alfis Arif \\ Program Studi Teknik Informatika Sekolah Tinggi Teknologi Pagar Alam \\ JalanMasik Siagim No.75 Simpang Mbacang Kec.Dempo Tengah Kota Pagar Alam \\ Sur-el : alfisarif@yahoo.com
}

\begin{abstract}
Abstrak: Tujuan penelitian ini adalah untuk merancang dan membangun website Dinas Pengendalian Penduduk Keluarga Berencana, Pemberdayaan Perempuan dan Perlindungan Anak Kota Pagar Alam menggunakan bahasa pemrograman PHP (Hyper Text Preprocessor), MYSQL sebagai database, dan xampp untuk web server, serta didukung dengan software yang lain seperti Adobe Dreamweaver, axure dan Google Chrome. Metodologi yang digunakan dalam perancangan website menggunakan metode web Engineering yang mempunyai 5 tahapan antara lain customer communication (komunikasi pelangan), planning (Perencanaan), modelling (Pemodelan), construction (Pembuatan), dan deployment (Penyebaran). Hasil yang di inginkan dengan adanya website Dinas Pengendalian Penduduk Keluarga Berencana Pemberdayaan Perempuan dan Perlindungan Anak Kota Pagar Alam dapat dengan mudah dalam melakukan pekerjaan terutama bagi petugas yang memberikan informasi serta memudahkan masyarakat dan Dinas Instansi Lainnya yang ingin mencari informasi tentang Dinas Pengendalian Penduduk Keluarga Berencana Pemberdayaan Perempuan dan Perlindungan Anak Kota Pagar Alam yang tepat dan akurat.
\end{abstract}

\section{Kunci Utama: Website, Web Engineering,PHP dan MySQL.}

\begin{abstract}
The purpose of this research is to design and build the website of Family Planning Control Service, Women Empowerment and Child Protection of Pagar Alam City using PHP programming language (Hyper Text Preprocessor), MYSQL as database, and xampp for web server, and supported by other software such as Adobe Dreamweaver, axure and Google Chrome. The methodology used in the design of the website using web engineering method that has 5 stages including customer communication (communication pelangan), planning (Planning), modeling, construction, and deployment. The desired result with the Family Planning Service Family Empowerment website of Women Empowerment and Child Protection of Pagar Alam City can easily do the job especially for officers who provide information and facilitate the community and other agencies who want to find information about Family Planning Department Family Planning Empowering Women and Child Protection Pagar Alam City precise and accurate.
\end{abstract}

Keywords : Website, Web Engineering, PHP and MySQL. 


\section{PENDAHULUAN}

Dunia teknologi dan ilmu pengetahuan pada saat ini berkembang pesat, mengakibatkan banyak perubahan yang terjadi dalam kehidupan manusia. Dengan adanya perkembangan teknologi ini setiap pekerjaan akan dapat direalisasikan secara lebih efisien dan efektif. Sebelum adanya komputer, dalam menjalankan ektifitas terasa begitu lamban dan membutuhkan banyak waktu. Dengan adanya teknologi komputer, dapat mempercepat segala aktivitas yang akan dilakukan dengan waktu yang lebih singkat. Khususnya di dalam bidang sistem pengolahan data agar menjadi sebuah informasi yang tepat dan akurat (Ricky T. Djaelangkara, 2015). Saat ini internet menjadi bagian dari kehidupan masyarakat modern. Mudahnya akses internet yang bisa dilakukan menjadikan pengguna internet semakin bertambah dari hari kehari. Tak hanya remaja dan orang dewasa saja, anak-anak sekarang juga bisa melakukan akses ke internet melalui PC atau pun Ponsel (Nilasari, 2014). Percepatan informasi website didukung dengan sebuah teknologi bernama internet, sebuah jaringan dunia dimana akses informasi mengirim dan menerima. Dalam internet terdapat website-website yang memberikan informasi yang di butuhkan oleh setiap orang. Web tersebut menjadi sebuah tempat berbagi informasi. Media website tersebut dimanfaatkan oleh berbagai pihak dari mulai yang bersifat pribadi sampai memenuhi kebutuhan suatu instansi perusahaan/pemerintah seperti blog, jejaring sosial, online shop, personal profil, company profile, sistem Informasi dan lain-lainnya. Oleh karena itu perusahaan-perusahaan system developer (pembuat sistem) tersebut banyak yang beralih mengikuti pasar bisnis yaitu dengan menggunakan Sistem Informasi berbasis website. Dengan kebutuhan akses informasi yang cepat, tepat dan akurat para developer tersebut mau tidak mau harus mengikuti perkembangan jaman, yaitu dengan menggunakan media informasi berbasis website. Sehingga hal ini dapat menjadi suatu point tambahan dalam persaingan bisnis setiap perusahaan (Muhammad Irsyad, 2012). Salah satu aplikasinya yaitu world wide web $(W W W)$. Di awal perkembangannya world wide web hanya digunakan untuk kalangan akademisi dan riset, namun sekarang world wide web digunakan untuk bisnis dan hiburan.

Dinas Pengendalian Penduduk, Keluarga Berencana, Pemberdayaan Perempuan dan Perlindungan Anak (DPPKBP3A) yang berkedudukan sebagai unsur pelaksana yang menyelenggarakan urusan pemerintahan pada sub urusan pengendalian penduduk dan keluarga berencana dan sub urusan pemberdayaan perempuan dan perlindungan anak yang dipimpin oleh kepala Dinas berkedudukan di bawah dan bertanggung jawab kepada Walikota melalui Sekretaris Daerah.

Berdasarkan beberapa penelitian oleh : (Merzakun Nusuki, 2013) Pembuatan Website Sebagai Informasi pada Kantor Urusan Agama (KUA) Kecamatan Arjosari, Kantor Urusan Agama (KUA) Arjosari yang berada di Jln. Patrem Kecamatan Arjosari adalah suatu lembaga yang menangani hal keagamaan. Namun masih ada beberapa masyarakat yang kurang mengerti tentang kegiatan-kegiatan yang dilakukan oleh lembaga tersebut, serta informasi yang di terima kurang maksimal oleh masyarakat. Dengan 
berkembangnya teknologi informasi dan komunikasi sangat pesat, dan banyak media teknologi yang digunakan untuk memberikan informasi kepada publik, salah satunya dengan media website. Dari hasil penelitian Marzakun Nusuki dan Sukadi tersebut mampu membangun sebuah aplikasi web yang dapat diterima oleh masyarakat Kecamatan Arjosari yang khususnya dan masyarakat luas umumnya dalam memantau penyebaran informasi yang lebih efektif. Adapun metode - metode yang di gunakan di antaranya adalah metode interview, metode observasi, metode kepustakaan, metode analisis, metode perancangan metode testing dan metode implementasi.

Hasil penelitian dari Dinas PPKBP3A Kota Pagar Alam bahwa penyampaian informasi selama ini masih secara konvesional dengan membagikan brosur, spanduk, baleho dan sosialisasi ke desa - desa. Dari permasalahan tersebut maka Dinas PPKBP3A Kota Pagar Alam perlu adanya sebuah website untuk mempermudah memberikan informasi kepada masyarakat luas dan maka dengan adanya website pada Dinas PPKBP3A Kota Pagar Alam masyarakat dengan mudah mengakses dan mengetahui segala sesuatu mengenai kegiatan dan informasi yang diberikan dengan cepat tanpa mengeluarkan waktu yang lama, biaya yang mahal dan tidak harus mengetahui informasinya dari Dinas PPKBP3A Kota Pagar Alam. Website ini berfungsi untuk memberikan informasi mengenai program kegiatan yang diberikan oleh Dinas PPKBP3A Kota Pagar Alam. Peranan website ini juga tidak terlepas dari penggunaan peralatan yang mampu mengatasi kelemahankelemahan yang mengandalkan tenaga manusia.

\section{METODE PENELITIAN}

Dalam penelitian ini peneliti menggunakan metode pengembangan sistem web engineering atau rekayasa web. Menurut (Rohmat Taufiq, 2013) Proses WebE dalam kerangka proses generic sebagai berikut :

\section{Customer communication} (Komunikasi dengan Pengguna)

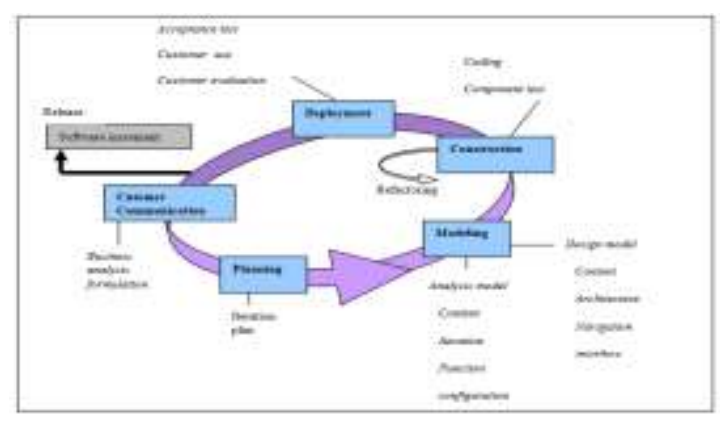

Gambar 1: web engineering

Komunikasi dengan pengguna/Dinas PPKBP3A Kota Pagar Alam tentang mengidentifikasi hal-hal yang akan termuat di website, dan menentukan siapa saja calon pengguna website. Tujuannya adalah untuk mendeskripsikan masalah yang perlu diselesaikan WebApp (termasuk kebutuhan dasar WebApps) menggunakan informasi yang ada. Upaya ini dilakukan untuk mengidentifikasikan ketidakpastian dan perubahan yang mungkin akan terjadi.

\section{Planning (Perencanaan)}

Perencanaan peluncuran proyek WebApp dilakukan Perencanaanya terdiri dari definisi tugas dan jadwal pekerjaan untuk jangka waktu tertentu (biasanya dalam waktu mingguan) yang 
diproyeksikan untuk peluncuran WebApp.

\section{Modelling (Pemodelan)}

Teknisi software konvensional menganalisa dan mendesain tugas yang diadaptasikan untuk mengembangkan WebApp, menggabungkan, dan kemudian menyatukannya dalam kegiatan pemodelan Webe. Tujuanya adalah untuk mengembangkan analisa "cepat" dan mendesain model yang menetapkan kebutuhan dan waktu yang sama merepresentasikan sebuah WebApp yang akan memuaskan mereka.

\section{Construction (Kontruksi)}

Perangkat WebE dan teknologinya diaplikasikan untuk membuat WebApp yang telah dijadikan model. Pada saat WebApp telah dibuat, serangkaian tes yang cepat dilakukan untuk mengukur kesalahan dalam desain tersebut (sebagai contoh isinya, arsitekturnya, interfacenya, navigasinya) diungkap. Pengujian tambahan juga dilakukan untuk mengetahui karakteritik lain dari WebApp

\section{Deployment (Penyebaran)}

WebApp dikonfigurasikan untuk lingkup operasionalnya, diluncurkan pada para pengguna akhir, dan kemudian adanya tahap evaluasi. Umpan balik diselesaikan pada tim WebE, dan perbaikan sesuai kebutuhan.

\subsection{Metode Pengumpulan Data}

Metode pengumpulan data merupakan suatu hal yang penting dalam penelitian, karena metode ini merupakan strategi atau cara yang digunakan oleh peneliti untuk mengumpulkan data yang diperlukan dalam penelitiannya. Untuk mendapat data yang dimaksud dalam penelitian dapat digunakan berbagai macam metode (Prof.DR.Eko Putrowidoyok, 2012).

\section{a. Metode Observasi}

Observasi biasa diartikan sebagai pengamatan dan pencatatan secara sistematim terhadap unsur-unsur yang nampak dalam suatu gejala pada objek penelitian. Unsur-unsur yang nampak itu disebut dengan data atau informasi yang harus diamati dan dicatat secara benar dan lengkap. Metode ini digunakan untuk melihat dan mengamati secara langsung keadaan di lapangan agar peneliti memperoleh gambaran yang lebih luas tentang permasalahan yang diteliti (Prof.DR.Eko Putrowidoyok, 2012).

\section{b. Metode Wawancara}

Wawancara merupakan suatu proses tanya jawab atau dialog secara lisan antara pewancara (interviewer) dengan responder atau orang yang diinterviu (interviewee) dengan tujuan untuk memperoleh informasi yang di butuhkan oleh peneliti. Wawancara merupakan cara pengumpulan data yang langgsung dari sumbernya tentang berbagai gejala sosial, baik yang terpendam (latent) maupun 
nampak. Wawancara merupakan alat yang sangat baik untuk mengetahui tanggapan, pendapat, keyakinan, perasaan, motivasi, serta proyeksi seseorang terhadap masa depannya. Wawancara di gunakan bila jumlah responden relatif sedikit (Prof.DR.Eko Putrowidoyok, 2012).

\section{c. Metode Dokumentasi}

Teknik yang berupa informasi dan berasal dari catatan penting baik dari lembaga atau organisasi maupun dari perorangan (Tamodia, 2013).

\section{d. Study Pustaka}

Penulis dengan pengumpulan data diperoleh dari buku-buku yang digunakan dan melalui beberapa situs internet dilakukan guna memperoleh data-data tambahan (Prof.DR.Eko Putrowidoyok, 2012).

\subsection{Usecase Diagram}




\subsection{Activity Diagram User}

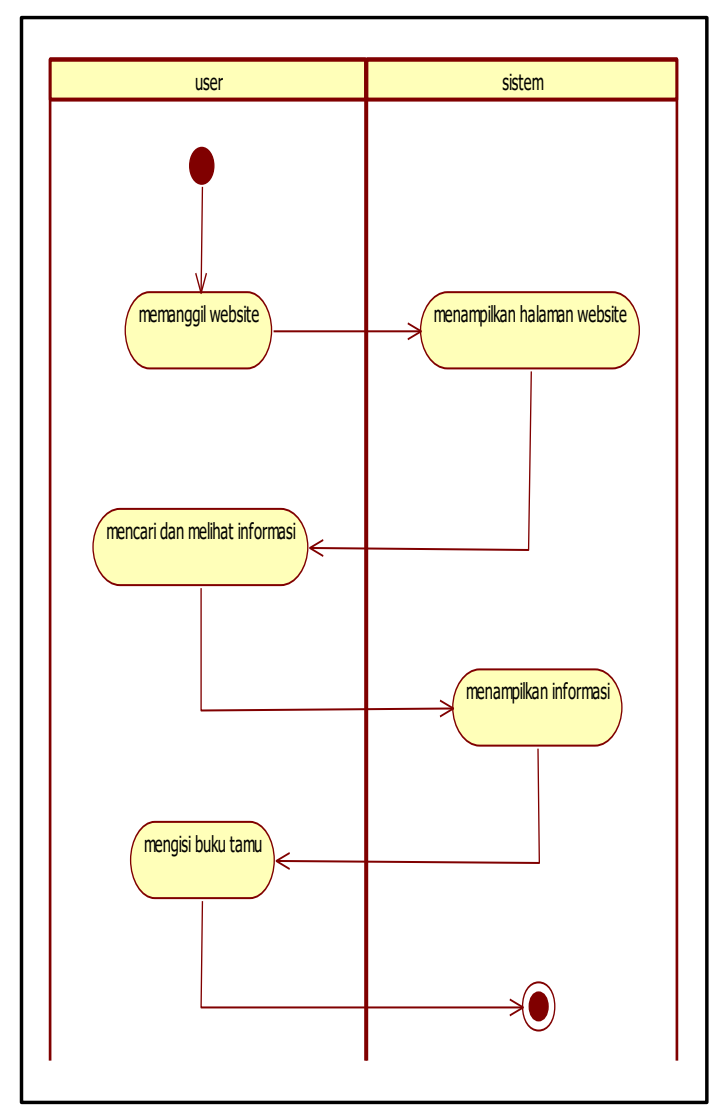

Gambar 4: Activity Diagram User

\subsection{Class Diagram}

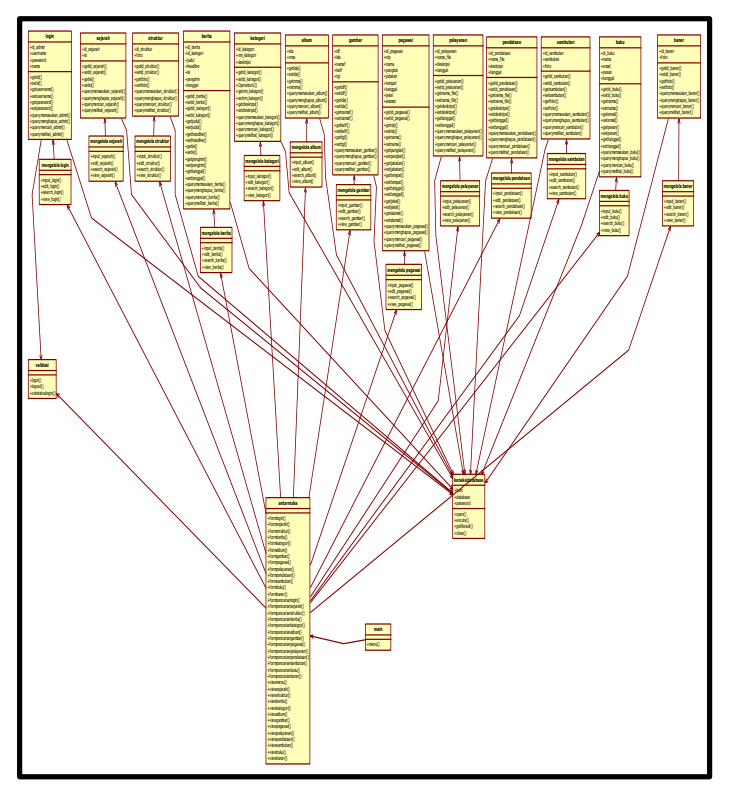

Gambar 5: Class Diagram

\subsection{Rancangan Tabel}

\section{Tabel 1. Sejarah}

\begin{tabular}{|c|c|c|c|c|}
\hline $\begin{array}{l}\mathrm{N} \\
\mathrm{O}\end{array}$ & $\begin{array}{l}\text { Nama } \\
\text { Variabel } \\
\end{array}$ & $\begin{array}{l}\text { Tipe } \\
\text { Data }\end{array}$ & $\begin{array}{l}\text { Panja } \\
\text { ng }\end{array}$ & Ket \\
\hline 1. & $\begin{array}{l}\text { Id_sejar } \\
a h\end{array}$ & Int & 5 & Primary Key \\
\hline 2. & Isi & Text & & \\
\hline
\end{tabular}

Tabel 2. Struktur

\begin{tabular}{lllll} 
No & $\begin{array}{l}\text { Nama } \\
\text { Variabel }\end{array}$ & $\begin{array}{l}\text { Tipe } \\
\text { Data }\end{array}$ & $\begin{array}{l}\text { Panja } \\
\text { ng }\end{array}$ & Ket \\
\hline 1. & Id_struktur & Int & 5 & $\begin{array}{l}\text { Primary } \\
\text { Key }\end{array}$ \\
\hline 2. & Foto & Varchar & 100 & \\
\hline
\end{tabular}

Tabel 3. Berita

\begin{tabular}{lllll}
\hline No & $\begin{array}{l}\text { Nama } \\
\text { Variabel }\end{array}$ & $\begin{array}{l}\text { Tipe } \\
\text { Data }\end{array}$ & $\begin{array}{l}\text { Panj } \\
\text { ang }\end{array}$ & Ket \\
\hline 1. & Id_berita & Int & 5 & $\begin{array}{l}\text { Prima } \\
\text { ry Key }\end{array}$ \\
\hline 2. & Id_kategori & Int & 5 & \\
\hline 3. & Judul & Varchar & 100 & \\
\hline 4. & Headline & Text & & \\
\hline 5. & Isi & Text & & \\
\hline 6. & Pengirim & Varchar & 20 & \\
\hline 7. & Tanggal & datetime & & \\
\hline
\end{tabular}

Tabel 4. Pegawai

\begin{tabular}{lllll}
\hline No & $\begin{array}{l}\text { Nama } \\
\text { Variabel }\end{array}$ & $\begin{array}{l}\text { Tipe } \\
\text { Data }\end{array}$ & $\begin{array}{l}\text { Pan } \\
\text { jan } \\
\mathrm{g}\end{array}$ & Ket \\
\hline 1. & Id_pegawai & Int & 5 & \\
\hline 2. & Nip & Varchar & 30 & $\begin{array}{l}\text { Primary } \\
\text { Key }\end{array}$ \\
\hline 3. & Nama & Varchar & 30 & \\
\hline 4. & Pangkat & Varchar & 50 & \\
\hline 5. & Jabatan & Varchar & 50 & \\
\hline 6. & Tempat & Varchar & 30 & \\
\hline 7. & Tanggal & Date & & \\
\hline 8. & Jekel & Varchar & 30 & \\
\hline 9. & Alamat & Text & & \\
\hline
\end{tabular}

Tabel 5. Pelayanan

\begin{tabular}{lllll}
\hline No & $\begin{array}{l}\text { Nama } \\
\text { Variabel }\end{array}$ & $\begin{array}{l}\text { Tipe } \\
\text { Data }\end{array}$ & $\begin{array}{l}\text { Pan } \\
\text { jan } \\
\mathrm{g}\end{array}$ & Ket \\
\hline $\begin{array}{l}\text { 1. } \\
\text { Id_pelayan } \\
\text { an }\end{array}$ & Int & 5 & $\begin{array}{l}\text { Primary } \\
\text { Key }\end{array}$ \\
\hline
\end{tabular}




\begin{tabular}{llll}
\hline 2. & Nama_file & Varchar & 100 \\
\hline 3. & Deskripsi & Varchar & 50 \\
\hline 4. & Tanggal & Date & \\
\hline
\end{tabular}

Tabel 6. Pendataan

\begin{tabular}{lllll}
\hline No & $\begin{array}{l}\text { Nama } \\
\text { Variabel }\end{array}$ & $\begin{array}{l}\text { Tipe } \\
\text { Data }\end{array}$ & $\begin{array}{l}\text { Panj } \\
\text { ang }\end{array}$ & Ket \\
\hline 1. & $\begin{array}{l}\text { Id_pendata } \\
\text { an }\end{array}$ & Int & 5 & $\begin{array}{l}\text { Primary } \\
\text { Key }\end{array}$ \\
\hline 2. & Nama_file & $\begin{array}{l}\text { Varc } \\
\text { har }\end{array}$ & 100 & \\
\hline 3. & Deskripsi & $\begin{array}{l}\text { Varc } \\
\text { har }\end{array}$ & 50 & \\
\hline 4. & Tanggal & Date & \\
\hline
\end{tabular}

\section{HASIL DAN PEMBAHASAN}

\subsection{Hasil}

Pada bab ini peneliti merancang Website pada Dinas Pengendalian Penduduk Keluarga Berencana Pemberdayaan Perempuan dan Perlindungan Anak Kota Pagar Alam, yang berguna untuk membantu atau melancarkan dalam memberikan informasi tentang Dinas PPKBP3A Kota Pagar Alam. Sistem atau langkah-langkah yang dilakukan dalam menyelesaikan desain sistem yang telah disetujui, untuk menguji dan memulai sistem yang baru dibuat.

Pada pembuatan website ini terdapat beberapa menu utama yang memiliki fungsi sesuai dengan kebutuhan dari pengguna yang telah ditentukan pada saat perencanaan aplikasi yang telah dirancang pada tahapan sebelumnya.

\section{Tabel 7: Pengujian Login}

\begin{tabular}{lllll}
\hline No & Test & $\begin{array}{l}\text { Prosedur } \\
\text { yang di } \\
\text { jalankan }\end{array}$ & $\begin{array}{l}\text { Hasil } \\
\text { yang di } \\
\text { harapka } \\
\text { n }\end{array}$ & $\begin{array}{l}\text { Hasil } \\
\text { Pengujia } \\
\text { n }\end{array}$ \\
\hline 1 & $\begin{array}{l}\text { Menu } \\
\text { Login } \\
\text { admin }\end{array}$ & $\begin{array}{l}\text { Masukkan } \\
\text { Username } \\
\text { dan }\end{array}$ & $\begin{array}{l}\text { Berhasil } \\
\text { masuk } \\
\text { ke }\end{array}$ & Berhasil \\
& & Password & & \\
\hline
\end{tabular}

halaman

admin

Tabel 8: Pengujian Profil

\begin{tabular}{|c|c|c|c|c|}
\hline No & Test & $\begin{array}{l}\text { Prosedur } \\
\text { yang di } \\
\text { jalankan }\end{array}$ & $\begin{array}{l}\text { Hasil } \\
\text { yang di } \\
\text { harapkan }\end{array}$ & $\begin{array}{l}\text { Hasil } \\
\text { Pengujian }\end{array}$ \\
\hline \multirow[t]{2}{*}{1} & $\begin{array}{l}\text { Menu } \\
\text { profil }\end{array}$ & $\begin{array}{l}\text { Input } \\
\text { field- } \\
\text { field } \\
\text { data } \\
\text { profil }\end{array}$ & $\begin{array}{l}\text { Data } \\
\text { profil } \\
\text { bertambah }\end{array}$ & Berhasil \\
\hline & & $\begin{array}{l}\text { Edit } \\
\text { data } \\
\text { profil }\end{array}$ & $\begin{array}{l}\text { Data } \\
\text { berubah }\end{array}$ & Berhasil \\
\hline
\end{tabular}

Tabel 9: Pengujian Berita

\begin{tabular}{|c|c|c|c|c|}
\hline No & Test & $\begin{array}{l}\text { Prosedur } \\
\text { yang di } \\
\text { jalankan }\end{array}$ & $\begin{array}{l}\text { Hasil } \\
\text { yang di } \\
\text { harapkan }\end{array}$ & $\begin{array}{l}\text { Hasil } \\
\text { Pengujian }\end{array}$ \\
\hline \multirow[t]{3}{*}{1} & $\begin{array}{l}\text { Menu } \\
\text { Berita }\end{array}$ & $\begin{array}{l}\text { Input } \\
\text { field- } \\
\text { field } \\
\text { data } \\
\text { berita }\end{array}$ & $\begin{array}{l}\text { Data } \\
\text { berita } \\
\text { bertambah }\end{array}$ & Berhasil \\
\hline & & $\begin{array}{l}\text { Edit } \\
\text { data } \\
\text { berita } \\
\end{array}$ & $\begin{array}{l}\text { Data } \\
\text { berubah }\end{array}$ & Berhasil \\
\hline & & $\begin{array}{l}\text { Hapus } \\
\text { data } \\
\text { berita }\end{array}$ & $\begin{array}{l}\text { Data ter } \\
\text { hapus }\end{array}$ & Berhasil \\
\hline
\end{tabular}

Tabel 10: Pengujian Galeri

\begin{tabular}{|c|c|c|c|c|}
\hline $\begin{array}{l}\mathrm{N} \\
\mathrm{O}\end{array}$ & Test & $\begin{array}{l}\text { Prosedu } \\
\text { r yang } \\
\text { di } \\
\text { jalankan }\end{array}$ & $\begin{array}{l}\text { Hasil } \\
\text { yang di } \\
\text { harapkan }\end{array}$ & $\begin{array}{l}\text { Hasil } \\
\text { Pengujia } \\
\mathrm{n}\end{array}$ \\
\hline \multirow[t]{3}{*}{1} & $\begin{array}{l}\text { Menu } \\
\text { Galeri }\end{array}$ & $\begin{array}{l}\text { Input } \\
\text { field- } \\
\text { field } \\
\text { data } \\
\text { galeri }\end{array}$ & $\begin{array}{l}\text { Data } \\
\text { galeri } \\
\text { bertamba } \\
\text { h }\end{array}$ & Berhasil \\
\hline & & $\begin{array}{l}\text { Edit } \\
\text { data } \\
\text { galeri }\end{array}$ & $\begin{array}{l}\text { Data } \\
\text { Berubah }\end{array}$ & Berhasil \\
\hline & & $\begin{array}{l}\text { Hapus } \\
\text { data } \\
\text { galeri }\end{array}$ & $\begin{array}{l}\text { Data ter } \\
\text { hapus }\end{array}$ & Berhasil \\
\hline
\end{tabular}


Tabel 11: Pengujian Informasi

\begin{tabular}{|c|c|c|c|c|}
\hline No & Test & $\begin{array}{l}\text { Prosedur } \\
\text { yang di } \\
\text { jalankan }\end{array}$ & $\begin{array}{l}\text { Hasil } \\
\text { yang di } \\
\text { harapkan }\end{array}$ & $\begin{array}{l}\text { Hasil } \\
\text { Pengujian }\end{array}$ \\
\hline \multirow[t]{4}{*}{1} & $\begin{array}{l}\text { Men } \\
\mathrm{u} \\
\text { Infor } \\
\text { masi }\end{array}$ & $\begin{array}{l}\text { Input } \\
\text { Field- } \\
\text { field data } \\
\text { informasi }\end{array}$ & $\begin{array}{l}\text { Data } \\
\text { informasi } \\
\text { bertambah }\end{array}$ & Berhasil \\
\hline & & $\begin{array}{l}\text { Edit data } \\
\text { informasi }\end{array}$ & $\begin{array}{l}\text { Data } \\
\text { berubah }\end{array}$ & Berhasil \\
\hline & & $\begin{array}{l}\text { Hapus } \\
\text { data } \\
\text { informasi }\end{array}$ & $\begin{array}{l}\text { Data ter } \\
\text { hapus }\end{array}$ & Berhasil \\
\hline & & $\begin{array}{l}\text { Download } \\
\text { data } \\
\text { informasi }\end{array}$ & $\begin{array}{l}\text { Data ter } \\
\text { download }\end{array}$ & Berhasil \\
\hline
\end{tabular}

Jadi dapat disimpulakan bahwa hasil pengujian pada website Dinas PPKBP3A Kota Pagar Alam sudah berhasil dalam pengujian sesuai dengan menu yang tersedia seperti menu login dalam memasukkan username dan password sudah berhasil, menu profil dalam meng Input field-field data profil dan meng Edit data profil sudah berhasil, menu Berita untuk Input field-field data berita, edit berita dan hapus data berita sudah berhasil, menu galeri untuk Input field-field data galeri, edit galeri dan hapus data galeri sudah berhasil, menu informasi untuk Input field-field data informasi, edit informasi, hapus data informasi dan download informasi sudah berhasil, dan menu buku tamu untuk mengirim pesan dan menghapus pesan sudah berhasil.

\subsection{Pembahasan}

Adapun cara menjalankan website ini yaitu dengan cara buka Google Chrome setelah itu ketik http://localhost/dinas_ppkbp3apga/ yang kemudian akan muncul website Dinas PPKBP3A Kota Pagar Alam.

\subsubsection{Tampilan Halaman Utama}

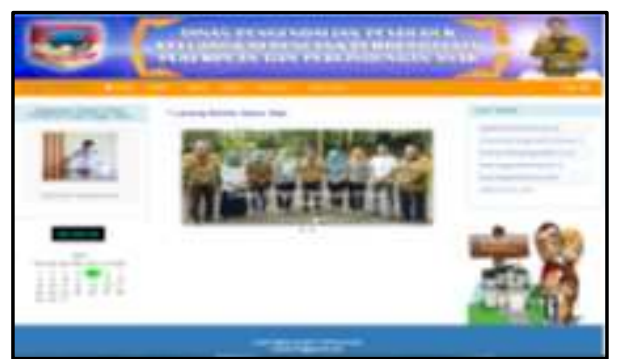

Gambar 6: Halaman Utama

\subsubsection{Tampilan Login Administrator}

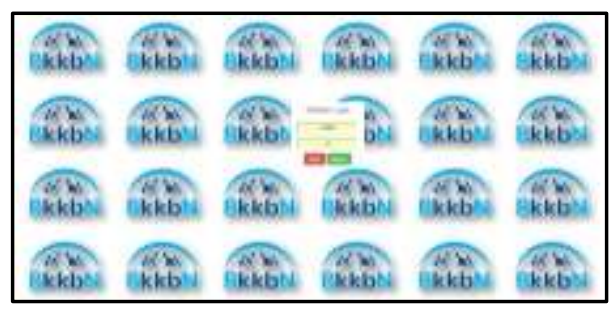

Gambar 7: Halaman Login Admin

\subsubsection{Tampilan Halaman Utama}

\section{Administrator}

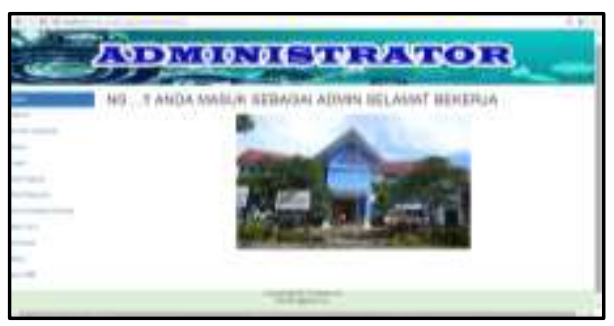

Gambar 8: Halaman Menu Utama

Admin

\subsubsection{Tampilan Halaman Kelola Sejarah}

Admin

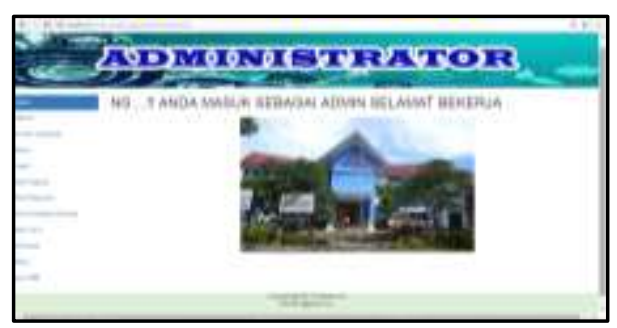

Gambar 0: Halaman Menu Utama

Admin 


\subsubsection{Tampilan Halaman Kelola Sejarah} Admin

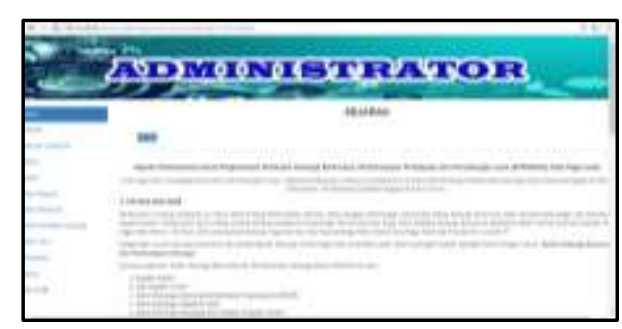

Gambar 10: Halaman Menu Sejarah Admin

\subsubsection{Halaman Edit Sejarah}

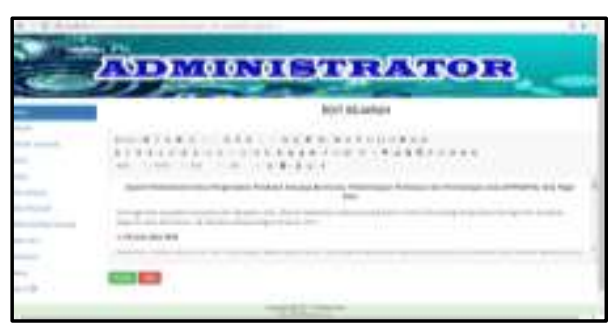

Gambar 11: Halaman Edit Sejarah

3.2.7 Halaman Struktur Organisasi Admin

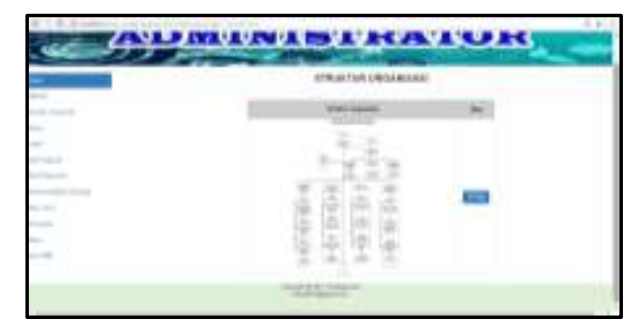

Gambar 12: Halaman Menu Struktur

Organisasi

3.2.8 Halaman Edit Struktur Organisasi Admin

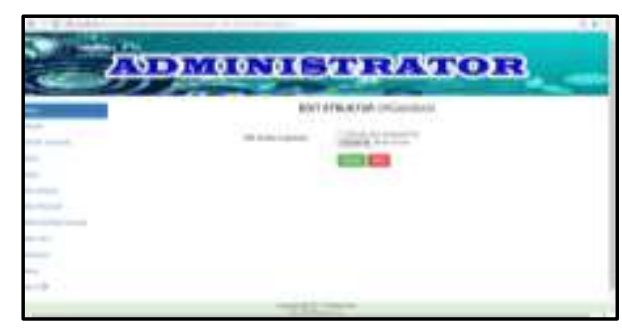

Gambar 13: Halaman Edit Struktur Organisasi Admin

\subsubsection{Halaman Berita Admin}

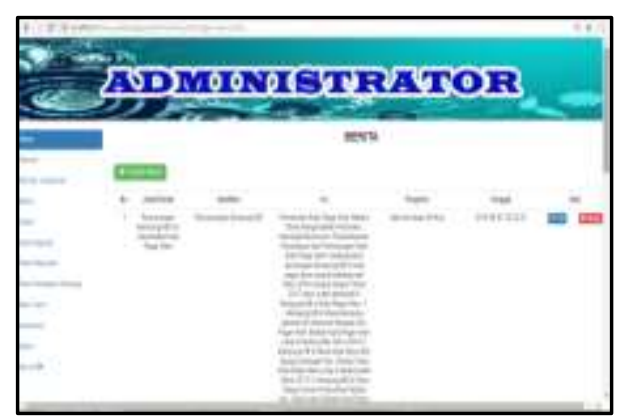

Gambar 14: Halaman Berita Admin

3.2.10 Halaman Utama User

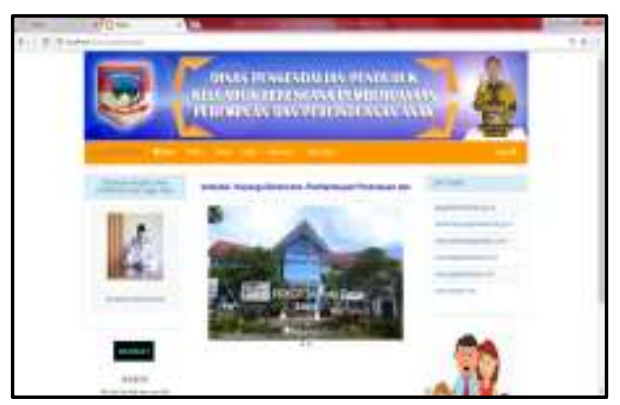

Gambar 15: Halaman Utama User

\subsubsection{Halaman Sejarah User}

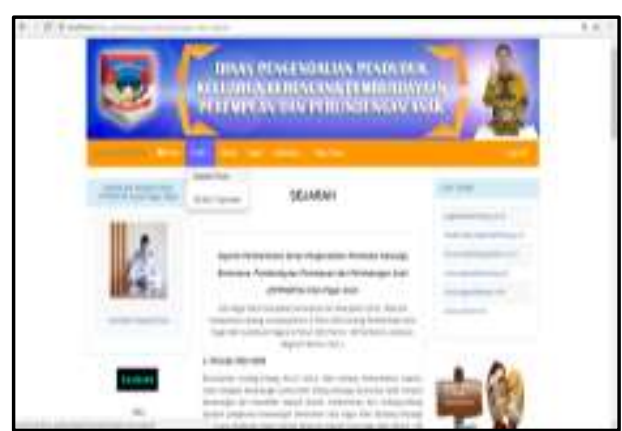

Gambar 16: Halaman Sejarah User

\subsubsection{Halaman Struktur Organisasi User}

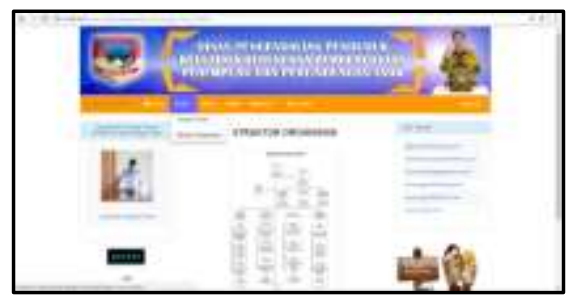

Gambar 17: Halaman Struktur Organisasi User 


\subsubsection{Halaman Berita User}

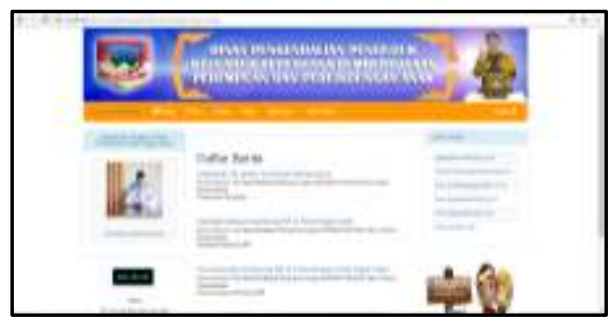

Gambar 18: Halaman Berita User

\subsubsection{Halaman Galeri User}

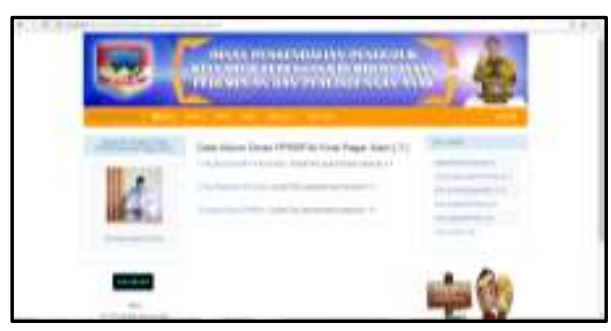

Gambar 19: Halaman Berita User

\subsubsection{Halaman Galeri User}

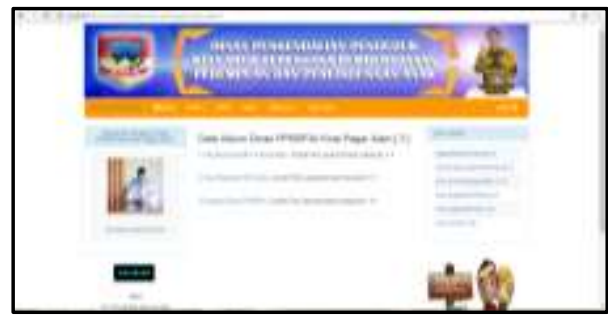

Gambar 20: Halaman Galeri User

\subsubsection{Halaman Album Foto User}

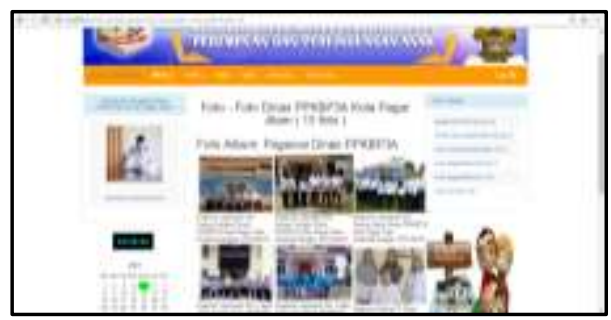

Gambar 21: Halaman Album Foto

User

\section{SIMPULAN}

Website Dinas PPKBP3A Kota Pagar

Alam, telah berhasil di buat dan dalam pembuatannya peneliti menggnakan bahasa pemrograman PHP (Personal Home Page) dan HTML (Hyper Text Markup Language), serta pengelolaan database-nya menggunakan MySQL (My Structure Query Language). Informasi yang disampaikan dalam website ini yaitu Profil Dinas Sejarah, Struktur Organisasi, Berita Dinas, Galeri, Data Pegawai, Data Pelayanan, Data Pendataan Keluarga. Dalam website ini yang memiliki hak akses adalah admin untuk mengelola data - data yang ada di dalam website ini.

Beberapa keuntungan dengan dibuatnya website ini, yaitu:

1. Dapat dengan mudahnya dalam menyampaikan informasi tentang dinas dan juga mempermudah pihak - pihak yang ingin mendapatkan informasi dengan cepat, dan dapat di akses kapan saja dan dimana saja;

2. Informasi yang disampaikan up to date karena website ini bersifat dinamis, dimana informasi - informasi yang disampaikan bisa selalu di perbaharui setiap saat, sesuai dengan kebutuhan;

3. Website ini bisa menjadi media resmi Dinas PPKBP3A Kota Pagar Alam dalam mempublikasikan profil Dinas PPKBP3A Kota Pagar Alam ke masyarakat umum.

\section{DAFTAR RUJUKAN}

Merzakun Nusuki, S. (2013). Pembuatan Website Sebagai Informasi pada Kantor Urusan Agama (KUA) Kecamatan Arjosari. Pembuatan Website Sebagai Informasi pada Kantor Urusan Agama (KUA) Kecamatan Arjosari, 1.

Muhammad Irsyad, C. S. (2012). Perancangan Website Sekolah Pada Subsystem User Iinterface. Perancangan Website Sekolah Pada Subsystem User Iinterface, 1. 
Nilasari, S. (2014). Jago Membuat Website Gratis Dan Cepat Secara Otodidak. JAKARTA: DUNIA KOMPUTER.

Prof.DR.Eko Putrowidoyok, M. (2012). Teknik Penyusunan Instrumen Penelitian. yogyakarta: pustaka pelajar.

Ricky T. Djaelangkara, R. S. (2015). Perancangan Sistem Informasi Akademik Sekolah Berbasis Web Studi Kasus Sekolah Menengah Atas Kristen 1 Tomohon. Perancangan Sistem Informasi Akademik Sekolah Berbasis Web Studi Kasus Sekolah Menengah Atas Kristen 1 Tomohon, 1.

Rohmat Taufiq, S. (2013). Sistem Informasi Manajemen. yogyakarta: Ghaha Ilmu.

Tamodia, W. (2013). Evaluasi Penerapan Sistem Pengendalian Intern untuk Persediaan Barang Dagangan pada PT.Laris Manis Utama Cabang Manado. Evaluasi Penerapan Sistem Pengendalian Intern untuk Persediaan Barang Dagangan pada PT.Laris Manis Utama Cabang Manado, 27. 